\title{
Strengthening the Twenty-first Century Skills of University Students in Facing ASEAN Economic Community
}

\author{
Mery Berlian ${ }^{1}$, Rian Vebrianto ${ }^{2}$, Alaniyah Syafaren 3 \\ DOI : 10.35445/alishlah.v13i3.535
}

\section{Article Info}

Keywords:

the 21st-century skills; competition;

ASEANeconomic community

Kata kunci:

keterampilan abadke-21;

kompetisi;

Komunitas ekonomi

ASEAN

\begin{abstract}
This study aims to determine the strengthening of the 21st Century Skills of UPBJJ Pekanbaru and Pangkal Pinang students in dealing with the ASEAN economic community (MEA). The 21st Century Skills strengthening study was motivated by the low competition in economic politics in Indonesia. The study involved 379 students selected based on study programs at the Pekanbaru Open University and Pangkal Pinang. Data in the form of opinions and statements were collected using a questionnaire in the form of a questionnaire and essay. Data obtained were analyzed qualitatively and quantitatively. The results showed that UPBJJ Pekanbaru and Pangkal Pinang students were qualitatively ready to perform 21st-century skills, including digital era literacy, inventive thinking, memorable communication, high productivity, and spiritual norms and values. Based on quantitative data, there is no significant difference in strengthening the 21 st Century Skills of UPBJJ Pekanbaru and Pangkal Pinang students.
\end{abstract}

\begin{abstract}
Abstrak
Penelitian ini bertujuan untuk mengetahui Penguatan Keterampilan Abad 21 Mahasiswa UPBJJ Pekanbaru dan Pangkal Pinang dalam menghadapi Masyarakat Ekonomi Asean (MEA). Kajian penguatan Keterampilan Abad 21 dilatarbelakangi oleh rendahnya persaingan dalam politik ekonomi di Indonesia. Penelitian ini melibatkan 379 mahasiswa yang dipilih berdasarkan program studi di Universitas Terbuka Pekanbaru dan Pangkal Pinang. Data berupa pendapat dan pernyataan dikumpulkan dengan menggunakan angket berupa angket dan karangan. Data yang diperoleh dianalisis secara kualitatif dan kuantitatif. Hasil penelitian menunjukkan bahwa secara kualitatif mahasiswa UPBJJ Pekanbaru dan Pangkal Pinang sudah siap menampilkan keterampilan abad 21 meliputi literasi era digital, pemikiran insentif, komunikasi yang mudah diingat, produktivitas tinggi, serta nilai dan norma spiritual. Berdasarkan data kuantitatif tidak terdapat perbedaan yang signifikan dalam penguatan Keterampilan Abad 21 Mahasiswa UPBJJ Pekanbaru dan Pangkal Pinang.
\end{abstract}

\footnotetext{
${ }^{1}$ Un iv ersitas Terbuka, Pekanbaru and In donesia

Email:mery@ecampus.ut.ac.id

2 Un iv ersitas Islam Negeri Sultan Syarif Kasim Riau, Pekanbaru and In donesia

Em ail: rian.vebrianto@uin-suska.ac.id

3 Un iv ersitas Islam Negeri Sultan Sy arif Kasim Riau, Pekanbaru and Indonesia

Em a il: alaniyah.syafaren@gmail.com
} 


\section{INTRODUCTION}

Indonesian students have joined the twenty-first century, which requires fundamental talents or skills such as digital literacy, critical thinking, effective communication, high productivity, and adherence to values and spiritual norms. These competencies or talents now address the issues of the fourth industrial revolution, which necessitates innovative education that prepares students to participate in the ASEAN Economic Community (AEC). The ASEAN Economic Community (AEC) is a Southeast Asian free-market organization designed to boost the ASEAN countries' economies. The ASEAN Economic Community's mission is to enhance economic stability in the ASEAN region, which has a direct impact on the development of a free market in investment, commodities and services, as well as human resources (HR) 2015 (Andriani); 2016 (Utami); 2018 (Sofi'i). Observed that Indonesia's membership in this community resulted in the emergence of workforce-level competencies and the capabilities and problems that must be overcome (Prayitno, 2016); (Ummah et al., 2019).

The ability that the students must possess is essential knowledge. The knowledge is obtained with various skills of the five pillars of education described by (Nurman et al., 2018). The five pillars of education include learning to believe in God, know, do, learn to be, and live together. The 21st century requires critical thinking, creative, collaborative, metacognitive, communication skills, information technology literacy, being lifelong learners based on good emotional, social and spiritual intelligence and as citizens of the world (Santyasa, 2018); (Wulan et al., 2018). The development and the implementation of the students' activities in the institution of higher education, as expressed by (Dinata et al., 2016), are intended to be a strategy to increase the competence of its graduates, which cover: Reasoning and Science, Talent and Interest, Welfare, and Social Activities.

Student activity aims to prepare the quality human resources in facing the AEC. Therefore, it requires the relationship between academic culture and organizational management systems. There are five dimensions as a way of building the relationship between those two: dimensions of authority, dimensions of schools, dimensions of quality, dimensions of recognition and dimensions of generosity (Ninlawan, 2015). The 21st-century skills are about attitudes, skills and knowledge, and technology and critical thinking that counterbalance (Martini, 2018).

One of the 21st-century skills is to support student motivation and interest in entrepreneurship. The skills needed for the advancement of the nation and state are the 21st Century Skills integrated and designed within the learning activities to deal with current or future challenges (Lukitasari et al., 2017). The 21st-century skills must be mastered by the students in the globalization era (Wulan et al., 2018), the teachers are the spearhead in preparing quality human resources (Maryani \& Damayanti, 2016). In addition, the 21st-century educators are expected to be capable of designing innovative learning to create a comfortable and peaceful learning atmosphere and make it easier for students to realize their ideas as a renewal in the world of education in which they can compete in the international world (Hasibuan \& Prastowo, 2019).

The problem currently faced is the low skill of the community, especially students, college students, teacher candidates and higher education institutions, in supporting the electability of human resources. The quality of Indonesian human resources is low due to a lack of quality education (Rizal, 2016). Learning at the college level has not been specifically designed to train 21st-century student skills (Lukitasari et al., 2017). Furthermore, institutions' ability to implement knowledge sharing, productivity, mastery of English and expertise is still low (Lufiana et al., 2018). In addition, the research results conducted by (Nurman et al., 2018) showed that the students' metacognitive skills were in the very risk category, and the students' scientific attitude was in a low category.

The inability to improve the quality of human resources creates impacts such as low ability to think, organization, and literacy, which even increases the unemployment rate. The impact caused 
low students 'critical thinking skills, low ability to solve student problems, students' ability to communicate ideas that are not yet optimal, and students have not been able to access scientific information accurately (Lukitasari et al., 2017). Entrepreneurial student interest is still low, and entrepreneurship campaigns are also not adequate (Putra et al., 2018).

According to Parker and Lazaro's assertion, 21st-century talents are more vital than basic and technical skills (Vebrianto et al., 2020). Malik (2018) reports that in science, problem-solving, innovation, and communication classrooms, 21st Century Skills are prioritized. Nonetheless, some educators expressed concern about the evaluation process in The 21st Century Skills. This is because digital integration into the learning process must consider the student's interest in the process (Lin et al., 2017). In 2020, Indonesia and Malaysia will confront economic issues due to the Asia Pacific Free Trade Area's (FTA-AP) economics (Rahmah, 2015). In Malaysia, the strengthening of The 21st Century Skills for digital literacy, imaginative thinking, effective communication, high productivity, and the norm and spirituality of teacher candidates is more than in Indonesia. In both countries, norms and spiritual values are classified similarly (strongly agree). The findings of this study indicate that there are only minor differences in the possibilities for Indonesian teachers compared to Malaysian teachers, particularly when it comes to abilities such as digital literacy, imaginative thinking, effective communication, and high productivity (Vebrianto et al., 2020).

Considering the influence and inability of higher education to increase human resources, a study was done at UPBJJ Pekanbaru and Pangkal Pinang to determine the uniqueness of students' 21st-century knowledge in outer and primary sectors. The issues examined relate to the 21stcentury skills in which NCREL and Metiri Group are engaged, including digital era literacy, imaginative thinking, effective communication, high productivity, and spiritual standards and values (Arnentis, 2018).

\section{METHODS}

This study employed a quantitative design using a survey research method on strengthening 21st Century Skills of UPBJJ Pekanbaru and Pangkal Pinang students. The instrument used for this study was The questionnaire of 21st-century skills. The questionnaire on 21st-century skills was developed based on the skills listed on the enGauge 21st-century skills by The Metiri Group (NCREL) (Tuan Soh et al., 2010).

The questionnaire for 21st-century skills is 30 items to represent the five constructs (Digital Age Literacy, Inventive Thinking, Effective Communication, High Productivity and moral Values and Spirituality). Since the instrument was adopted from previous studies, we can consider this instrument valid. In addition, a pilot study was conducted to obtain the reliability index of the instrument was 0.84. it is considered acceptable to good (Mallery \& George, 2016) since the closer the alpha is to 1 , the greater the internal consistency of the items. This study was conducted on 373 students. Data collection techniques used questionnaires on a Likert and essay scale. The data obtained were analyzed descriptively and tested quantitatively testing by SPSS version 20.

\section{FINDINGS AND DISCUSSION}

This research was conducted from July to August 2019 participated by 272 students of UPBJJ Pekanbaru and 101 students of UPBJJ Pangkal Pinang. The data obtained is the result of a questionnaire given to the students with several assessment components. Based on the assessment components of strengthening students' 21st century skills, including digital literacy, inventive thinking, effective communication, high productivity, norms and spiritual values, it shows that the students of UPBJJ Pekanbaru and Pangkal Pinang are ready to face the Asean Economic Community. The results of the data will be described and discussed as follows.

\section{Digital Literacy Skill}

The questions are given to determine the students' digital literacy skills include (B1) MEA Concepts, (B2) Articles, (B3) Information, (B4) Essay Writing, (B5) Ideas, (B6) Knowledge, (B7) 
Productivity, (B8) Product Principle, (B9) technology literacy, (B10) Issues and (B11) Concern which can be seen in the following Table 1.

Table 1. Digital Literacy of UPBJJ Pekanbaru dan Pangkal Pinang Students

\begin{tabular}{|c|c|c|c|c|c|c|}
\hline \multirow[b]{2}{*}{ Question } & \multicolumn{3}{|c|}{ UPBJJ Pekanbaru } & \multicolumn{3}{|c|}{ UPBJJ Pangkal Pinang } \\
\hline & Average & $\begin{array}{l}\text { Question } \\
\text { Average }\end{array}$ & $\begin{array}{l}\text { Question } \\
\text { Category }\end{array}$ & Average & $\begin{array}{l}\text { Question } \\
\text { Average }\end{array}$ & $\begin{array}{l}\text { Question } \\
\text { Category }\end{array}$ \\
\hline $\mathrm{B} 1$ & $3 \cdot 7$ & & & 3.8 & & \\
\hline B2 & 3.7 & & & $3 \cdot 7$ & & \\
\hline B3 & $3 \cdot 7$ & & & 3.8 & & \\
\hline B4 & 3.4 & & & 3.6 & & \\
\hline B5 & 3.6 & & & 3.7 & & \\
\hline B6 & 3.8 & $3 \cdot 7$ & Agree & 4.0 & 3.8 & Agree \\
\hline B7 & 3.7 & & & 3.7 & & \\
\hline B8 & $3 \cdot 5$ & & & 3.7 & & \\
\hline B9 & 3.7 & & & 3.8 & & \\
\hline B10 & $3 \cdot 5$ & & & 3.6 & & \\
\hline B11 & 4.2 & & & 4.0 & & \\
\hline
\end{tabular}

Table 1 shows that the highest questions assessment is found in B11, 4.2 and 4.0, concerning the awareness of the AEC issues. It is then followed by $\mathrm{B} 6=4.0$ and $3.8, \mathrm{~B} 1, \mathrm{~B} 3$ and $\mathrm{B} 9=3.8$ and $3.7, \mathrm{~B} 2, \mathrm{~B} 7=3.7, \mathrm{~B}_{5}=3.6$ and $3.7, \mathrm{~B} 8=3.5$ and $3.7, \mathrm{~B} 1 \mathrm{O}=3.5$ and 3.6 and $\mathrm{B} 4=3.4$ and 3.6. The lowest number is on $\mathrm{B} 4$, which is the essay writing about AEC. In addition, the total average of UPBJJ Pangkal Pinang is 3.8, which is higher than Pekanbaru with 'agree' for each question category.

The low score or value of UPBJJ Pekanbaru and Pangkal Pinang students on B4 for writing essays about the AEC issues becomes the thing that should be worried about. It is a line of research conducted by (Kahar, 2018), the level of digital literacy of students is very low on the component of looking for local potential information and sharing information. This is likely based on the inability to use technology and the internet (Sukor et al., 2010) that the economy influences social status, i.e. those in the high economy get higher scores of internet use than those in the low economy.

The economic factors are not entirely a problem since the research results by (van Laar et al., 2017) show that the 21st-century skills are not necessarily supported by the use of information and communication technology. The low interest in writing essays is influenced by internet usage that is not too intense. The students who access the internet 5 hours a day almost use the internet for social media and instant messaging (Adiarsi et al., 2015). This is the basis of the low interest of the students in writing essays on the Asean Economic Community (AEC).

One of the efforts needed to deal with this problem is to use the SCL method in each course taken by the students. The teaching and learning process can combine the SCL method with a concept map in which the students can understand reading materials and write scientific papers to be competent in the AEC era (Thahroni \& Hartati, 2018).

\section{Inventive Thinking Skill}

The assessment of students' creative thinking skills includes ( $\mathrm{C} 1)$ Revolutionary, (C2) Problem Solving, (C3) Design, (C4) Interests, (C5) Assignments Acceptance, (C6) Flexible thinking shown in Table 2. It shows that the highest value is on $\mathrm{C}_{3}$ and $\mathrm{C}_{2}, 4.2,4.1$, and 4 . Those are then followed by $\mathrm{C}_{3}=4$ and 3,9, $\mathrm{C} 1$ and $\mathrm{C} 6=3,9$ and 3,8 and $\mathrm{C}_{5}=3,6$ and 3,7 with 'agree' for each question category. The lowest assessment value lies on question 5, which is the assignment acceptance even though they do not have the confidence to face it. The fact is that the students are also required to think inventively, like creative thinking, to find the innovation or new creativity. It pointed out that creativity can generate new thoughts useful for any field (Atmadja \& Saputra, 2018). 
Table 2. Inventive Thinking Skill of UPBJJ Pekanbaru and Pangkal Pinang Students

\begin{tabular}{ccccccc}
\hline \hline \multirow{2}{*}{ Question } & \multicolumn{3}{c}{ UPBJJ Pekanbaru } & \multicolumn{3}{c}{ UPBJJ Pangkal Pinang } \\
\cline { 2 - 6 } & Average & $\begin{array}{c}\text { Question } \\
\text { Average }\end{array}$ & $\begin{array}{c}\text { Question } \\
\text { Category }\end{array}$ & Average & $\begin{array}{c}\text { Question } \\
\text { Average }\end{array}$ & $\begin{array}{c}\text { Question } \\
\text { Category }\end{array}$ \\
\hline C1 & 3.8 & & & 3.9 & \\
C2 & 4.0 & & & 4.1 & \\
C3 & 3.9 & \multirow{2}{*}{3.8} & Agree & 4.0 & 4.0 & Agree \\
C4 & 4.0 & & & 4.2 & \\
C5 & 3.6 & & & 3.7 & & \\
C6 & 3.8 & & & 3.9 & & \\
\hline
\end{tabular}

Inventive thinking is very much needed in 21st-century skills, as explained by (Ali, 2014). Inventive thinking is one of the 21st-century skills that is important for gaining insight for educated citizens. Creativity with some flexibility components is obtained by the Construction Principle, The Reality Principle, and The Self-Assessment Principle. Creativity as the result of inventive thinking is intended to face the AEC, so it needs the competence explained by (Haryati, 2016) that personality / intrapersonal skills and social competence / interpersonal skills or commonly called soft skills are needed because the character is more important than technical knowledge and skills.

The institution of higher education has to train the students and the prospective educators to face the AEC with inventive thinking. MoEYS in (Vong \& Kaewurai, 2017) explained that educational institutions must train competent human resources to have high capacities, knowledge skills, morality, creative and inventive ideas, and critical thinking. Besides, the use of technology by teachers in the Technological Pedagogical Content Knowledge (TPACK) component is still essential in this era (Kurniawan et al., 2018).

\section{Effective Communication Skill}

The assessment of students' practical communication skills includes (D1) Organization, (D2) Communicative, (D3) Community Problems, (D4) Responsibility, (D5) Sosuli as shown in Table 3 below.

Table 3. The Effective Communication of UPBJJ Pekanbaru dan Pangkal Pinang Students

\begin{tabular}{llllccc}
\hline \hline \multirow{2}{*}{ Question } & \multicolumn{4}{l}{ UPBJJPekanbaru } & \multicolumn{3}{l}{ UPBJJPangkalPinang } \\
\cline { 2 - 6 } & Average & $\begin{array}{c}\text { Question } \\
\text { Average }\end{array}$ & $\begin{array}{l}\text { Question } \\
\text { Category }\end{array}$ & Average & $\begin{array}{c}\text { Question } \\
\text { Average }\end{array}$ & $\begin{array}{c}\text { Question } \\
\text { Category }\end{array}$ \\
\hline D1 & 4.1 & & & 4.2 & & \\
D2 & 3.9 & & 4.1 & & Strongly \\
D3 & 3.6 & 4.0 & Agree & 3.9 & 4.1 & Agree \\
D4 & 4.0 & & & 4.2 & & \\
D5 & 4.1 & & & 4.2 & & \\
\hline
\end{tabular}

Table 3 shows that the highest assessment value of questions is in D1 and D5 with 4.1 and 4.2, followed by $\mathrm{D} 4=4.2$ and 4, D2 $=4.1$ and 3.9, and the lowest assessment value is found in D3 with 3.9 and 3.6. There is a difference in the category of UPJJ Pekanbaru (agree) and Pangkal Pinang (strongly agree). The lowest value is found in D3, which is resolving conflicts that arise between group members. This issue is the basis for the need for ways to overcome problems in practical communication skills.

The conflicts which are difficult to overcome indeed become complex problems that require different efforts for each cause. Many problems faced in the 21st century related to work, technology, and solutions have not yet been found (Fayomi et al., 2019). The use of social media can influence the damage to effective communication between groups or communities. Emoticons can be used to reinforce message content, provide support, insinuate someone, express feelings of sadness, express feelings of shame, give encouragement, apologize, express feelings of 
disappointment, and express feelings of gratitude. Therefore, WhatsApp emoticons may not be used carelessly (Alfian Cholis Purnomo, 2018).

Realizing effective communication requires the encouragement of group institutions and social organizations in the form put forward by (Astuti, 2018) which sets out the forms of social interaction according to the number of perpetrators. b) Interaction between an individual with the individual. c) Interactions between individual and group, d) Interaction between group and group. The purpose of communication between groups is to motivate entrepreneurship skills. Mia et al. (2018) pointed out that emotional intelligence contributes effectively to entrepreneurial motivation.

\section{High Productivity Skill}

High Productivity Skills observed include (E1) Designing Schedule, (E2) Reflection, (E3) Technology Literacy, (E4) Product Assessment. The results can be seen in Table 4 .

Table 4. High Productivity Skill of UPBJJ Pekanbaru dan Pangkal Pinang Students

\begin{tabular}{ccccccc}
\hline \multirow{2}{*}{ Question } & \multicolumn{3}{c}{ UPBJJ Pekanbaru } & \multicolumn{3}{c}{ UPBJJ Pangkal Pinang } \\
\cline { 2 - 7 } & Average & $\begin{array}{c}\text { Question } \\
\text { Average }\end{array}$ & $\begin{array}{l}\text { Question } \\
\text { Category }\end{array}$ & Average & $\begin{array}{c}\text { Question } \\
\text { Average }\end{array}$ & $\begin{array}{l}\text { Question } \\
\text { Category }\end{array}$ \\
\hline E1 & 3.9 & & & 3.9 & & \\
E2 & 3.9 & \multirow{2}{*}{3.9} & Agree & 3.9 & 4.0 & Agree \\
E3 & 3.9 & & & 4.1 & & \\
E4 & 3.8 & & & 4.0 & & \\
\hline
\end{tabular}

Table 4 shows that the assessment value of $\mathrm{E}_{3}$ is higher at 4.1 and 3.9 in technology literacy. It is followed by E4 $=3.8$ and 4.0 , and $\mathrm{E} 1$ and $\mathrm{E} 2$, which get 3.9 with the 'agree' category.

E1 and E2 have the same average number, but they are lower than E4 and E3. E1 and E2 show a low value in setting the time to prepare and reflect on each task. The use of technology is still low, which makes the problem solving using information sources is not yet optimal. It then becomes the basis that the teachers or prospective teachers are still self-taught towards the use of technology to answer all the problems they face as revealed by (Faizatul Amalia, Adam Hendra Brata, Rizki Tri Sulistyo, 2018) that most teachers know the information, not from those around them, but curiosity in finding technology that can be used in his work.

Technologies such as social media and others are already utilized in everyday life. However, the students are still unable to reflect on all the problems given, even though smartphones make it easier for them to ask friends and even lecturers. Prijama et al. (2018) and Ekie et al. (2019) revealed that the use of smartphones and internet access or online information affects academic achievement, which increases academic values and quality .

\section{Norms and Spiritual Values Skill}

The norms and spiritual values skill become additional assessment to see the students' spiritual attitudes, including (F1) Science and Technology with God, (F2) Islamic Values, (F3) Human Interaction, (F4) Skills Enhancement. The data obtained are shown in Table 5 below.

Table 5. Norms and Spiritual Values of UPBJJ Pekanbaru dan Pangkal Pinang Students

\begin{tabular}{ccccccc}
\hline \hline \multirow{2}{*}{ Question } & \multicolumn{2}{l}{ UPBJJ Pekanbaru } & \multicolumn{2}{c}{ UPBJJ PangkalPinang } \\
\cline { 2 - 6 } & Average & $\begin{array}{c}\text { Question } \\
\text { Average }\end{array}$ & $\begin{array}{c}\text { Question } \\
\text { Category }\end{array}$ & Average & $\begin{array}{c}\text { Question } \\
\text { Average }\end{array}$ & $\begin{array}{c}\text { Question } \\
\text { Category }\end{array}$ \\
\hline F1 & 4.1 & & Strongly & 4.3 & & Strongly \\
F2 & 4.0 & \multirow{2}{*}{4.1} & Agree & 4.2 & 4.2 & Agree \\
F3 & 4.1 & & & 4.3 & & \\
F4 & 4.2 & & & & \\
\hline
\end{tabular}


Table 5 shows that the highest value is found in F4 with 4.3 and 4.2 to improve skills. It is then followed by $\mathrm{F} 1=4.3$ and 4.1, F3 $=4.2$ and 4.1, and the lowest assessment value of all questions found in F2 $=4.1$ and 4 with 'strongly agree' for all categories.

The lowest value on F2 shows that the science lecturers are still lacking in connecting science and Islamic values. A curriculum innovation or scientific integrity with religion is needed. The efforts to improve the quality of Islamic education formats and curriculum are needed to improve the quality of graduates in the ASEAN region (Samsul Nizar, 2016); (Marlina \& Iswati, 2018). In addition, the local Islamic wisdom has also been applied, as revealed by (Hunaepi, E Susantini, L Firdaus, T Samsuri, 2018), that inquiry learning tools integrated with local wisdom can be used in learning activities.

The assessment of 21st-century skills issues becomes a reflection for academic institutions to improve the quality of human resources. At the end of the assessment, the students are given the response essay to 21st Century skills consisting of (G1) Knowledge of AEC, (G2) Preparation, (G3) Relationship Skills, (G4) Expected Opportunities and (G5) Role and Benefits of UT UPBJJ. The results are shown in Table 6 below.

Table 6. The Response Average of UPBJJ Pekanbaru dan Pangkal Pinang Students

\begin{tabular}{cl}
\hline \hline & \multicolumn{1}{c}{ Average Correspondence Essay } \\
\hline G1 & Free tradebetween ASEANcountries \\
G2 & Increasing Knowledge and Skills in the Use of Technology \\
G3 & Science and Technology \\
G4 & Exports of Goods and Services \\
G5 & Increasing Knowledge \\
\hline
\end{tabular}

The data that has been described is then analyzed using SPSS 20 to find out the differences and significance between strengthening the 21st-century skills of UPBJJ UT Pekanbaru and statistics is widely applied in the SPSS (Statistical Package for the Social Sciences) program used in quantitative data processing (Zein et al., 2019). The results of the data obtained can be seen in Table 7 and Table 8 below.

Table 7. Variation of the 21st Century Skills in UPBJJ Pekanbaru and Pangkal Pinang

\begin{tabular}{lcccc}
\hline \hline & Levene's Test of Equality of Error Variances $^{\mathrm{a}}$ & \\
\hline & $\mathrm{F}$ & $\mathrm{df1}$ & $\mathrm{df2}$ & Sig. \\
\hline Digital Literacy & 0.771 & 1 & 6 & 0.414 \\
Inventive Thinking & 1.500 & 1 & 6 & 0.267 \\
Effective Communication & 0.794 & 1 & 6 & 0.407 \\
High Productivity & 2.455 & 1 & 6 & 0.168 \\
Norms andValues & 0.500 & 1 & 6 & 0.506 \\
\hline
\end{tabular}

Based on Table 7 , the variance of strengthening the 21st-century skills is significant $>0.05$, which indicates the same variance. It shows homogeneity between UPBJJ Pekabaru and Pangkal Pinang with the same data. A trial to find out the differences in strengthening the 21st-century skills can be seen in Table 8 below.

Table 8. The 21st Century Skills Differences of UPBJJ Pekanbaru and Pangkal Pinang

\begin{tabular}{llccc}
\hline \hline & Tests of Between-Subjects Effects & & & \\
\hline & Dependent Variable & df & F & Sig. \\
\hline & Digital Literacy & 1 & 1.263 & 0.304 \\
& Inventive Thinking & 1 & 3.857 & 0.097 \\
Corrected Model and Area & Effective Communication & 1 & 1.485 & 0.269 \\
& High Productivity & 1 & 3.429 & 0.114 \\
& Norms and Values & 1 & 3.947 & 0.094 \\
\hline
\end{tabular}


Table 8 shows a significant value $>0.05$, which proves no significant difference between UPBJJ Pekanbaru and Pangkal Pinang. The preparation of Indonesian human resources needs to be done consistently and sustainably through increasing primary and secondary school Gross Enrollment Ratio (GER), university GER; work training; improvement of English language skills; and the holding of professional certification as an effort to recognize the competence of Indonesian human resources (Prayitno, 2016).

The strategy of developing the quality of the education system must at least; 1) oriented to the development of international scale academic or ASEAN regional scale so that the academic and social needs for national and regional scale have been automatically able to be fulfilled; 2) implement an education management system based on quality improvement; 3) as an effort to internationalize education, the network of cooperation in developing educational institutions must be more comprehensive (international academic networking) in order to support the development of superior, innovative and productive domestic human resources, therefore, in the future, the educational institutions can reduce unemployment while creating graduates (row input) who are competent in various fields (Ginanjar, 2016).

\section{CONCLUSION}

Based on the results of the research, it can be concluded that: 1) strengthening the 21stcentury skills of UPBJJ Pekanbaru and Pangkal Pinang students are already in line with the expectation to create quality human resources; 2) based on the results of the Manova trial, it was found that there was no significant difference between strengthening the 21st-century skills of UPBJJ Pekanbaru and Pangkal Pinang students. In fact, the differences between the strengthening of the 21st Century Skills was still low. This, considering that the results of relations between the two regions had almost the same statistical relationship.

For this reason, special attention is needed for educational institutions in preparing 21stcentury skills for students to be ready to compete in any form and anywhere. This illustrates that knowledge and science are essential factors in facing the challenges in this era. This is an opportunity for further researchers to develop clearly how to implement 21st-century skills in the form of training and development for students in their institutions.

\section{REFERENCES}

Adiarsi, G. R., Stellarosa, Y., \& Silaban, M. W. (2015). Literasi Media Internet di Kalangan Mahasiswa. Humaniora, 6(4), 470. https://doi.org/10.21512/humaniora.v6i4.3376

Alfian Cholis Purnomo. (2018). Analisis Semiotika terhadap Penggunaan Emoticon WhatsApp Dalam Komunikasi Interpersonal Antar Mahasiswa Ilmu Komunikasi Angkatan 2013. In Program Studi Ilmu Komunikasi Fakultas Komunikasi dan Informatika Universitas Muhammadiyah Surakarta. Universitas Muhammadiyah Surakarta.

Ali, A. O. (2014). Pemerkasaan Pemikiran Inventif di Negara Brunei Darussalam: Satu Percubaan Awal Pengajaran Dan Pembelajarannya Dalam Mata Pelajaran Bahasa Melayu. Procedia Social and Behavioral Sciences, 134, 416-425. https://doi.org/10.1016/j.sbspro.2014.04.264

Andriani, C. (2015). Mahasiswa dan Perguruan Tinggi Dalam Era ASEAN Economic Community. Snema.

Arnentis, Y. F. A. (2018). Analisis Keterampilan Abad Ke-21 (21St Century Skills) Mahasiswa Pada Perkuliahan Teknik dan Manajemen Laboratorium Program Studi Pendidikan Biologi FKIP Universitas Riau. Prosiding Seminar Nasional Pendidikan Biologi, 21, 505-511.

Astuti, M. E. A. (2018). Dinamika Sosial Koperasi Mahasiswa. Socio - Politica, 8(2), 217-226. https://doi.org/10.1017/CBO9781107415324.004

Atmadja, A. T., \& Saputra, K. A. K. (2018). Pengaruh Budaya Universitas Terhadap Kinerja Mahasiswa Akuntansi Dengan Kreativitas Sebagai Variabel Moderasi (Studi Pada Mahasiswa Akuntansi Di Perguruan Tinggi Se-Kabupaten Buleleng). Jurnal Akuntansi Aktual, 5(1), 2230.https://doi.org/10.17977/umo04V5i12018po22

Dinata, P. A. C., Rahzianta, \& Zainuddin, M. (2016). Self Regulated Learning sebagai Strategi Membangun Kemandirian Peserta Didik dalam Menjawab Tantangan Abad 21. Seminar 
Nasional Pendidikan Sain, 1(1), 139-146.

Faizatul Amalia, Adam Hendra Brata, Rizki Tri Sulistyo, A. D. (2018). Analisis Tingkat Penerimaan Sistem E-Learning menggunakan Blog Gratis sebagai Alternatif Media Pembelajaran Pada Guru. Jurnal Teknologi Informasi Dan Ilmu Komputer, 5(3), 335-340. https://doi.org/10.25126/jtiik.201853640

Fayomi, O. O., Fayomi, O. S. I., Atiba, O. E., \& Ayuba, A. U. (2019). Failure of the 21st century researchers in solving national economic menace: A necessity. Energy Procedia, 157, 428434.https://doi.org/10.1016/j.egypro.2018.11.207

Ginanjar, M. H. (2016). Tantangan Dan Peluang Lembaga Pendidikan Islam Di Era Masyarakat Ekonomi Asean (Mea). An-Nidzam : Jurmal Manajemen Pendidikan Dan Studi Islam, 3(2), 107-124. https://doi.org/10.33507/an-nidzam.v3i2.14

Haryati, S. (2016). Peningkatan Profesionalisme Dosen Di dra MEA. Jurnal Ilmu Pendidikan, 3(1), $1-11$.

Hasibuan, A. T., \& Prastowo, A. (2019). Konsep Pendidikan Abad 21: Kepemimpinan Dan Pengembangan Sumber Daya Manusia Sd/Mi. MAGISTRA: Media Pengembangan Ilmu Pendidikan Dasar Dan Keislaman, 1O(1), 26-50. https://doi.org/10.31942/mgs.v10i1.2714

Hunaepi, E Susantini, L Firdaus, T Samsuri, R. (2018). Validitas Perangkat Pembelajaran Model Inkuiri Terintegrasi Kearifan Lokal untuk Melatih Keterampilan Berpikir Kritis dan Disposisi Berpikir Kritis Mahasiswa. Judika (Jurnal Pendidikan Unsika), 6(2), 47-58.

Kahar, A. P. (2018). ANALISIS LITERASI DIGITAL MAHASISWA CALON GURU BIOLOGI MELALUI PROYEK VIDEO AMATIR BERBASIS POTENSI LOKAL PADA MATA KULIAH EKOLOGI TUMBUHAN. Pedagogi Hayati. https://doi.org/10.31629/ph.v2i1.330

Kurniawan, R., Haizam Mohd Saudi, M., \& Raphael Wijaya, Z. (2018). The Influence of Brand Equity and STP towards Pricing Strategy and the Impact on Decision Making. International $\begin{array}{lllll}\text { Journal of Engineering \& Technology, } & \text { 3(4.34), }\end{array}$ https://doi.org/10.14419/ijet.v7i4.34.25304

Lin, M. H., Chen, H. C., \& Liu, K. S. (2017). A study of the effects of digital learning on learning motivation and learning outcome. Eurasia Journal of Mathematics, Science and Technology Education, 13(7), 3553-3564. https://doi.org/10.12973/eurasia.2017.00744a

Lufiana, U., Martono, T., \& Sudarno. (2018). Pengaruh Pembelajaran Kewirausahaan dan Bimbingan Karir terhadap Minat Berwirausaha Mahasiswa Pendidikan Ekonomi di Universitas Sebelas Maret pada Era Masyarakat Ekonomi Asean (MEA). BISE: Jurnal Pendidikan Bisnis Dan Ekonomi, 4(2).

Lukitasari, M., Handika, J., \& Murtafiah, W. (2017). 21st Century Skills Mahasiswa Calon Guru Dalam Pembelajaran Matematika. Prosiding Seminar Hasil Penelitian Dan Pengabdian Kepada Masyarakat UNIPMA, 4, 372-378.

Malik, R. S. (2018). Educational Challenges in 21St Century and Sustainable Development. Journal of Sustainable Development Education and Research, 2(1), 9. https://doi.org/10.17509/jsder.v2i1.12266

Mallery, P., \& George, D. (2016). IBM SPSS Statistics 23 Step by Step: A Simple Guide and Reference. Routledge.

Marlina, M., \& Iswati, I. (2018). Pengembangan Kurikulum PTAI Menghadapi Masyarakat Ekonomi ASEAN (MEA). Al-I'tibar: Jurnal Pendidikan Islam, 5(1), 1-9. https://doi.org/10.30599/jpia.v5i1.305

Martini, E. (2018). Membangun Karakter Generasi Muda Melalui Model Pembelajaran Berbasis Kecakapan Abad 21. Jurnal Pancasila Dan Kewarganegaraan, 3(2), 21-27. https://doi.org/10.24269/jpk.v3.n2.2018.pp21-27

Maryani, I., \& Damayanti, V. (2016). Identifikasi Permasalahan Guru di Indonesia Dalam Menghadapi Asean Economic Community (AEC). Prosiding Seminar Nasional "Optimalisasi Active Learning Dan Character Building Dalam Meningkatkan Daya Saing Bangsa Di Era Masyarakat Ekonomi Asean (MEA).

Ninlawan, G. (2015). Effect of Academic Culture in Administration of Private School to be Ready to Asian Economic Community (AEC). Procedia - Social and Behavioral Sciences, 197(February), 1580-1585. https://doi.org/10.1016/j.sbspro.2015.07.114

Nurman, R., Hala, Y., \& Bahri, A. (2018). Profil Keterampilan Metakognitif dan Sikap Ilmiah Mahasiswa Jurusan Biologi FMIPA UNM. Prosiding Seminar Nasional Biologi Dan Pembelajarannya, 371-376. 
Prayitno, H. (2016). Peningkatan kapasistas sumber daya manusia (SDM) Indonesia di era Masyarakat Ekonomi ASEAN.

Putra, R. P., Wirasari, I., \& Hidayatulloh, M. (2018). Perancangan Kampanye "Cekatan" Untuk Peningkatan Minat Wirausaha Pada Mahasiswa. E-Proceeding of Art \& Design.

Rahmah, A. (2015). Digital Literacy Learning System for Indonesian Citizen. Procedia Computer Science, 72, 94-101.https://doi.org/10.1016/j.procs.2015.12.109

Rizal. (2016). Mengajar Cara Berpikir, Meraih Ketrampilan Abad 21. Seminar Nasional Pendidikan PGSD UMS \& HDPGSDI Wilayah Jawa Pendidikan, 390-406. http://hdl.handle.net/11617/9134

Samsul Nizar. (2016). Pendidikan Islam di Era Masyarakat Ekonomi ASEAN. Akademika, 11(1), $43-62$.

Santyasa, I. W. (2018). Student centered learning : Alternatif pembelajaran inovatif abad 21 untuk menyiapkan guru profesional. Prosiding Seminar Nasional Quantum, 25, 14 .

Sofi'i, I. (2018). Peranan Pendidikan Islam Dalam Menghadapi Tantangan Masyarakat Economi Asean (Mea). Jurnal Madani : Ilmu Pengetahuan, Teknologi Dan Humaniora, 1(1), 103-122. https://doi.org/10.33753/madani.v1i1.6

Sukor, N. S., Osman, K., \& Abdullah, M. (2010). Students' achievement of Malaysian 21st Century Skills in Chemistry. Procedia - Social and Behavioral Sciences, 9(December), 1256-1260. https://doi.org/10.1016/j.sbspro.2010.12.316

Thahroni, \& Hartati, R. (2018). Pengaruh metode SCL dipadu peta konsep terhadap pemahaman bacaan dan menulis karya ilmiah dalam era MEA. Psychopolytan (Jurnal Psikologi), 2(1), 58-64.

Tuan Soh, T. M., Arsada, N. M., \& Osman, K. (2010). The Relationship of 21st Century Skills on Students' Attitude and Perception towards Physics. Procedia - Social and Behavioral Sciences, 7(2), 546-554.https://doi.org/10.1016/j.sbspro.2010.10.073

Ummah, S. K., Inam, A., \& Azmi, R. D. (2019). Creating manipulatives: Improving students' creativity through project-based learning. Journal on Mathematics Education, 1O(1), 93-102. https://doi.org/10.22342/jme.10.1.5093.93-102

Utami, T. K. (2016). Analisis tentang Pendidikan tan Pelatihan terhadap Peningkatan Kompetensi Pegawai Negeri Sipil Dalam Menghadapi Masyarakat Ekonomi Asean (MEA). Jurnal Mimbar Justitia, 2(1), 743-758.

van Laar, E., van Deursen, A. J. A. M., van Dijk, J. A. G. M., \& de Haan, J. (2017). The relation between 21st-century skills and digital skills: A systematic literature review. Computers in Human Behavior, 72, 577-588. https://doi.org/10.1016/j.chb.2017.03.010

Vebrianto, R., Jannah, M., Putriani, Z., Syafaren, A., \& Gafur, I. A. (2020). Comparative Analy sis of Strengthening of Skills of The 21st Century Teaching Candidates in Indonesia and Malaysia. Revista Espacios, 23(41).

Vong, S. A., \& Kaewurai, W. (2017). Instructional model development to enhance critical thinking and critical thinking teaching ability of trainee students at regional teaching training center in Takeo province, Cambodia. Kasetsart Journal of Social Sciences, 38(1), 88-95. https://doi.org/10.1016/j.kjss.2016.05.002

Wulan, A. R., Isnaeni, A., \& Solihat, R. (2018). Penggunaan Asesmen Elektronik Berbasis Edmodo Sebagai Assessment for Learning Keterampilan Abad 21. Indonesian Journal of Educational Assesment, 2(1), 1-10.https://doi.org/10.26499/ijea.v1i2.7

Zein, S., Yasyifa, L., Ghozi, R., Harahap, E., Badruzzaman, F., \& Darmawan, D. (2019). Pengolahan dan Analisis Data Kuantitatif Menggunakan Aplikasi SPSS. Jurnal Teknologi Pendidikan Dan Pembelajaran, 4(1), 1-7. 